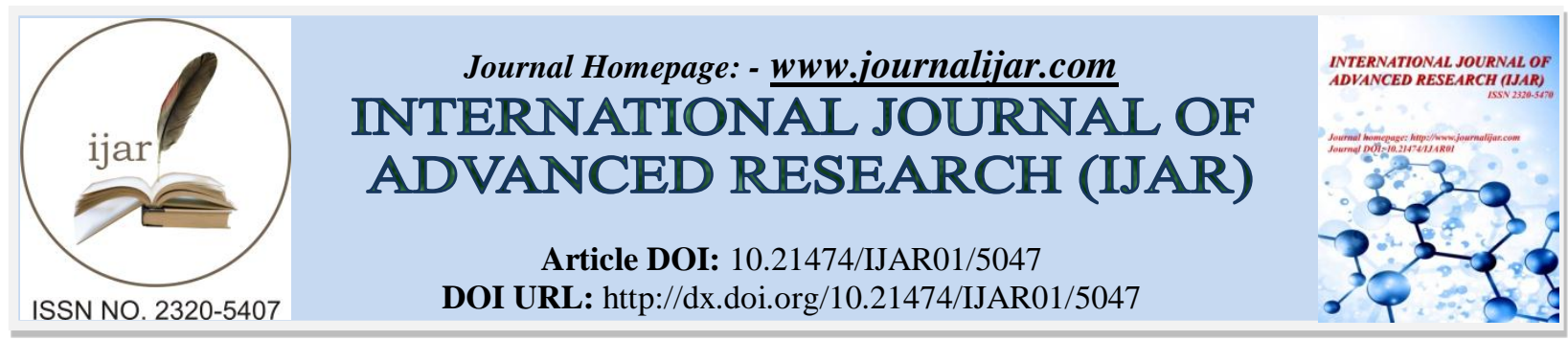

RESEARCH ARTICLE

\title{
AN EXPERIMENTAL STUDY OF INJECTION PARAMETER ON EMISSION PERFORMANCE IN TURBOCHARGED DIESEL AND BIODIESEL ENGINE FOR OFF-ROAD APPLICATIONS.
}

Arvind TD, Vignesh B and S. Dinesh.

Department of Automobile Engineering, Saveetha School of Engineering, Saveetha University.

\section{Manuscript Info}

Manuscript History

Received: 02 June 2017

Final Accepted: 04 July 2017

Published: August 2017

\begin{abstract}
The internal combustion engine is the key to the modern society. Without transportation performed by the millions of vehicles on road and at sea we would not have reached today's living standard. There are two types of internal combustion engines, namely, the Spark Ignition (SI), and the Compression Ignition (CI). Petrol and diesel are at present the principal fuels for SI and CI engines, respectively These fuels square measure on the verge of obtaining extinct, and through combustion, these fuels unharness a considerable quantity of pollutants into the atmosphere and build environmental connected issues. The internal combustion (IC) engine is known to be one of the major sources of air pollution in the environment fuel oxidisation method within the engine generates not solely helpful power, however conjointly a substantial quantity of waste emissions together with carbonic acid gas (CO2), monoxide (CO), unburned organic compound (HC), chemical element Oxides (NOx), and particulate (PM). Tests were conducted on a Twin cylinder internal-combustion engine with a compression quantitative relation of 18.5. Diesel is injected directly into the cylinder at an optimum injector needle pressure of $230 \mathrm{bar}, 240$ bars, and 250bars. In diesel engines, it is highly desirable to reduce the amount of NOx in the exhaust gas. We check the Performance (BSFC, Brake thermal efficiency and emission (Smoke Level and Amount of $\mathrm{HC}, \mathrm{NO}_{\mathrm{x}}, \mathrm{CO}, \mathrm{CO}_{2}, \mathrm{O} 2$ ) of the Engine in the process and compare it to turbocharged biodiesel engine with the Naturally Aspirated condition.
\end{abstract}

Copy Right, IJAR, 2017,. All rights reserved.

\section{Introduction:-}

Diesel engines are a compression ignition sort of burning engine. it's well-known technology in achieving a serious improvement in fuel economy and significant duty task presently. Diesel engines are normally utilised in significant duty application vehicles like constructional vehicles, trucks, and lorries. But now it is widely implemented in light vehicles such as cars and vans. Diesel engines can double the fuel economy than spark ignition engines in light vehicles. Diesel engines use fuel injection system. The fuel injection system is a system used to supply fuel into internal combustion engine which replaced carburettor function to supply the fuel into the engine. Fuel injector atomises the fuel by forcibly pumping it through a small injection nozzle under high pressure. It is because diesel engine ignites the fuel by the high temperature created by the compression of air and fuel mixture. Diesel engines have many advantages such as high fuel efficiency, reliability, and durability. The performance of diesel engines depends on many parameters. One of the important parameters which influence the performance of diesel engines is 
fuel injection pressure. Fuel injection pressure plays an important aspect of power performance of the engine to obtain combustion treatment.

\section{Fuel injection system:-}

Fuel injection is a technology that is being used in most of the cars and other automotive transportation these days. The technology is used to eliminate the need for carburettors. The technology helps the engine to supply fuel directly to the cylinder in the intake manifold, eliminating the use if carburetor to much extent. Overall, the fuel injection is required to supply fuel directly to the engine. The system works by the fuel is directly supplied to the cylinder in the intake chamber. Sensors located in such engines will regulate the flow of fuel injected and maintains it to appropriate levels. As long as the sensors which are usually electronic are working properly, the possibilities of breakdown and choke are immensely reduced.

\section{Turbo charging:-}

A turbocharger is a device used to allow more power to be produced for an engine of a given size. A turbocharged engine can be more powerful and efficient than a naturally aspirated engine because the turbine forces more intake air, proportionately more fuel, into the combustion chamber than if atmospheric pressure alone is used. A turbocharger is made up of two main sections. The rotary engine and therefore the mechanical device. The rotary engine consists of the rotary engine wheel and therefore the rotary engine housing. it's the duty of the rotary engine housing to guide the exhaust gas into the rotary engine wheel. The energy from the exhaust gas turns the rotary engine wheel, and therefore the gas then exits the rotary engine housing through an exhaust outlet space. Its purpose is to extend the meter potency of the combustion chamber. varied new technologies are introduced to help the turbo charging of burning engine so the meter potency might improve additional. These technologies embrace inter-cooling of the charged air before going into the combustion chamber so its mass rate of flow is exaggerated. the opposite technology is twin charging within which first of all the engine is boosted by a compressor then it's boosted by a turbocharger once the energy of exhaust gas is comfortable to rotate the rotary engine blades.

\section{Experimental Setup and Procedure:-}

A single cylinder 4-stroke water-cooled direct injection diesel engine with a displacement volume of $1670 \mathrm{cc}$, compression ratio 18.5:1, developing $21 \mathrm{~kW}$ at $2000 \mathrm{rpm}$ with a dynamometer was used for the present research work. The specifications of the engine are listed in Table 4.1 The engine is fitted with conventional fuel injection system, which has a 5 hole nozzle of $0.262 \mathrm{~mm}$ separated at 146 degrees, inclined at an angle of 60 degrees to the cylinder axis. The injector opening pressure recommended by the manufacturer was 250 bar. The Bosch fuel pump which is fitted on the engine enables the automatic regulation of the engine speed. The combustion chamber is hemispherical in shape with the overhead valve arrangement operated by push rods. A provision was made to mount a piezoelectric pressure transducer flush with the cylinder head surface in order to measure cylinder pressure. The injection system of the engine was periodically cleaned and calibrated as recommended by the manufacturer. The specifications of the test engine are given in Table 1 .

Table 1:- Test Bed Engine Specification

\begin{tabular}{|l|l|}
\hline MODEL & S 217 \\
\hline Capacity & $21 \mathrm{~kW}$ (28 bhp @ 2000 rpm) \\
\hline Type / Configuration & Vertical in-line Diesel Engine \\
\hline Bore & $91.44 \mathrm{~mm}$ \\
\hline Stroke & $127 \mathrm{~mm}$ \\
\hline No. of Cylinders & 2 \\
\hline Displacement & $1670 \mathrm{cc}$ \\
\hline Compression ratio & $18.5: 1$ \\
\hline Cycle & 4 Stroke \\
\hline Rotation & Clockwise (viewed from front) \\
\hline Aspiration & Natural \\
\hline Combustion System & Direct Injection \\
\hline Fuel Pump & MICO Bosch Inline Pump \\
\hline Governing & Mechanical \\
\hline Engine Starting System & Electrical \\
\hline Cooling System & Water \\
\hline
\end{tabular}




\begin{tabular}{|l|l|}
\hline Electrical System & 12 Volts (Dynamo/Alternator) \\
\hline Flywheel Housing & SAE 1 or SAE 3 \\
\hline Flywheel & Can be made to suit application \\
\hline Weight (Bare Engine) & $200 \mathrm{~kg}$ \\
\hline Length x Width x Height & $489 \times 536 \times 756 \mathrm{nmm}$ \\
\hline Fan Centre from Crank Centre & $282.6 \mathrm{~mm}$ \\
\hline Power Take-off & $\begin{array}{l}\text { From Crankshaft axially or radially. Gear drove PTO } \\
\text { Training gears on LHS beneath Fuel Pump }\end{array}$ \\
\hline Air-compressor & Optional \\
\hline
\end{tabular}

Engine Instrumentation:-

Dynamometer:-

A dynamometer or "dyno" in brief could be a device for menstruation force, an instant of force (torque), or power. For instance, the facility made by an engine, motor or alternative rotating first cause will be calculated by at the same time measuring force and motion speed (rpm).

A dynamometer may also be accustomed confirm the force and power needed to work a driven machine like a pump. Therein case, driving or driving dynamometer is employed. A measuring device that's designed to be driven is termed an absorption or passive dynamometer. A dynamometer that may either drive or absorb is termed a universal or active dynamometer.

Table 2:- Dynamometer specification

\begin{tabular}{|l|l|}
\hline EDDY CURRENT DYNAMOMETER \\
\hline MODEL & E 50 \\
\hline Maximum Power & $100 \mathrm{bhp}(75 \mathrm{Kw})$ \\
& $@ 3000$ to $6000 \mathrm{rpm}$ \\
\hline Maximum Torque & $234 \mathrm{Nm} @ 1500$ to $3000 \mathrm{rpm}$ \\
\hline Accuracy of Torque Indication & $+0.25 \%$ of Max. Dyno Torque \\
\hline
\end{tabular}

\section{Pressure measurement:-}

A piezoelectric pressure transducer (Kistler Instruments, Switcher land, model 6613CQ09-01) was installed in the engine cylinder head to acquire the combustion pressure-crank angle history. The sensitivity of the pressure transducer is $25 \mathrm{PC} /$ bar. The pick up was the water-cooled type. The piezoelectric transducer produces a charge output, which is proportional to the in-cylinder pressure. Machining for installation of the pressure transducer was carried out in the cylinder head and the engine main shaft was coupled to a precision shaft encoder with the resolution of 0.50 crank angle. A TDC marker was used to locate the TDC position in every cycle of the engine. The cylinder pressure data were acquired for 50 consecutive cycles and then averaged in order to eliminate the effect of cycle-to-cycle variations. The personal computer (PC), through an analog to digital converter (ADC), reads the output of the charge amplifier. There is a small drift in the voltage measured $(-2 \mathrm{mV} / \mathrm{s})$ due to charge leakage in the pressure transducer. Since the signal from a piezoelectric transducer indicates only relative pressures, it is necessary to have a means of determining the absolute pressure at some point in the cycle. Hence, it had to be referenced to in order to get the actual pressure. This was done by assuming that the cylinder pressure at suction BDC is equal to the mean intake manifold pressure. The specification of the pressure transducer and the charge amplifier are given in Table 3 .

Table 3:- Specifications of pressure transducer and charge amplifier

\begin{tabular}{|l|l|}
\hline Model & KISTLER, Switzerland. 6613CQ09-01 \\
\hline Range & $0-200 \mathrm{bar}$ \\
\hline Sensitivity & $25 \mathrm{pC} / \mathrm{bar}$ \\
\hline Linearity & $0.1<+\% \mathrm{FSO}$ \\
\hline Acceleration sensitivity & $0.001 \mathrm{bar} / \mathrm{g}$ \\
\hline Operating temperature range & $-196-200^{\circ} \mathrm{C}$ \\
\hline Capacitance & $5 \mathrm{pF}$ \\
\hline Weight & $1.7 \mathrm{~g}$ \\
\hline Connector, Teflon insulator & $\mathrm{M} 4 * 0.35$ \\
\hline
\end{tabular}




\section{TDC position sensor:-}

The TDC position sensor was developed and used to indicate the position of TDC by providing a voltage pulse exactly when the TDC position was reached. This sensor consists of a matched pair of infrared diode and phototransistor so that infrared rays emitted from the diode fall on the phototransistor when it is not interrupted. A continuous disc with a small cut at the TDC position with respect to sensor point was made to get the signal when the piston reaches TDC exactly. At this point, the output voltage from phototransistor rises to 5 volts and at all the other points it is zero. Voltage signals from the optical sensor were fed to an analog to digital converter and then to the data acquisition system along with pressure signals for recording.

\section{Analog to Digital Converter:-}

Engine cylinder pressure and TDC signal are acquired and stored on a high-speed computer-based digital data acquisition system. A 24 bit analog to digital (A/D) converter was used to convert analog signals to digital signals. The A/D card had external and internal trigger facility and with sixteen ended channels. During experiments, data for 50 cycles are recorded and signals are then passed through specially developed software to obtain the combustion parameters.

\section{Load and speed measurement:-}

The engine was coupled to an electrical dynamometer to load it. The dynamometer controller allowed the engine to be operated in two different modes viz. constant speed and constant torque modes. Since the engine was equipped with speed governor the dynamometer was operated in the torque mode. Speed was measured with the aid of digital tachometer. The engine output was varied by controlling the field current. The dynamometer was calibrated statically by applying a known torque. The load was measured by the dynamometer with the help of a strain gauge type of load cell mounted between the stator base and the frame.

\section{Fuel flow rate measurement:-}

Fuel flow rate was measured on the volume basis using a burette and stopwatch. The fuel from the tank is sent to the engine through a graduated burette using a two-way valve. When the valve is set at position 1 the fuel is sent to the engine directly and in position 2 the fuel contained in the burette is sent to the engine. For the measurement of fuel flow rate of the engine, the valve is set at position 2 and the time for a definite quantity of the fuel flow is noted. This gives the fuel flow rate for the engine.

\section{Air flow rate measurement:-}

The inlet manifold of the engine is connected to the surge tank to avoid pressure fluctuation at the inlet. A calibrated turbine type flow meter is attached to the tank which is directed to the atmosphere. This is done with due care that there is no air leakage. During the engine operation, the air to the engine from the atmosphere is through the flow meter. The time required for the intake of a definite quantity of air gives the air flow rate of the engine.

\section{Temperature measurement:-}

The temperature of the exhaust gas was measured with ChromelAlumel (K-Type) thermocouples. A digital indicator with an automatic room temperature compensation facility was used and it was calibrated periodically.

\section{Exhaust Gas Analyser:-}

The use of a five-gas exhaust analyzer (AVL 444 DIAS) can be used to measure the exhaust gas emissions such as $\mathrm{CO}, \mathrm{CO} 2, \mathrm{HC}, \mathrm{O} 2$ and $\mathrm{NO}$ in the exhaust.

Table 4:- Specifications of the exhaust gas analyzer and smoke meter exhaust gas analyzer (AVL-444)

\begin{tabular}{|l|l|l|}
\hline S.No. & Details & Specifications \\
\hline Exhaust Gas Analyzer Measuring Ranges & \multicolumn{2}{|l|}{} \\
\hline 1 & Oxygen (O2) & $0-25.00 \%$ vol \\
\hline 2 & Carbon monoxide (CO) & $0-15.00 \%$ vol \\
\hline 3 & Carbon dioxide (CO2) & $0-20.00 \%$ vol \\
\hline 4 & Hydro carbon (HC) & $0-20,000 \mathrm{ppm}$-hexane \\
\hline 5 & Nitrogen oxide (NOx) & $0-2,000 \mathrm{ppm}$ \\
\hline 6 & $\begin{array}{l}\text { Excess Air calculated } \\
\text { According to Brett Schneider }\end{array}$ & $-40^{\circ} \mathrm{C}$ to $+650^{\circ} \mathrm{C}$ \\
\hline
\end{tabular}




\begin{tabular}{|l|l|l|}
\hline \multicolumn{2}{|l|}{} & Temperature \\
\hline 7 & Oxygen $(\mathrm{O} 2)$ & $0.1 \%$ or $3 \%$ \\
\hline 8 & Carbon monoxide $(\mathrm{CO})$ & $0.06 \%$ or $5 \%$ of measured value \\
\hline 9 & Carbon dioxide $(\mathrm{CO} 2)$ & $0.5 \%$ or $5 \%$ of measured value \\
\hline 10 & Hydro carbon $(\mathrm{HC})$ & $12 \mathrm{ppm}$ or $5 \%$ of measured value \\
\hline 11 & Nitrogen oxide $(\mathrm{NOx})$ & $5 \mathrm{ppm}$ or $5 \%$ of measured value \\
\hline 12 & Temperature $(\mathrm{T}>250 \mathrm{oC})$ & $1 \%(\mathrm{~T}<150 \mathrm{oC}) 2 \%(\mathrm{~T}<250 \mathrm{oC}) 3 \%$ \\
\hline Resolution & \multicolumn{2}{|l|}{} \\
\hline 13 & Oxygen $(\mathrm{O} 2)$ & $0.01 \%$ \\
\hline 14 & Carbon dioxide $(\mathrm{CO} 2)$ & $0.1 \%$ \\
\hline 15 & Carbon monoxide $(\mathrm{CO})$ & $0.01 \%$ \\
\hline 16 & Hydro carbon $(\mathrm{HC})$ & $1 \mathrm{ppm}$ \\
\hline 17 & Nitrogen oxide $(\mathrm{NOx})$ & $1 \mathrm{ppm}$ \\
\hline
\end{tabular}

\section{Smoke measurement:-}

The exhaust smoke level was measured by using a standard AVL smoke measuring apparatus. This measuring instrument consists of a sampling pump that sucks a definite quantity $(330 \mathrm{cc})$ of exhaust sample through a white filter paper. The reflectivity of the filter paper was then measured using a standard Bosch smoke meter that consists of a light source and an annular photodetector surrounding it. Before every sampling, it was ensured that the exhaust from the previous measurement was completely driven off from the tube and pump. The photographic view of the smoke meter is shown in Figure 4.5. The specifications of the smoke meter are given in Table 5.

Table 5:- Technical specification of AVL 437 Smoke Meter

\begin{tabular}{|l|l|l|}
\hline $\begin{array}{l}\text { S. } \\
\text { No }\end{array}$ & Particulars & Specifications \\
\hline 1 & Accuracy and Reproducibility & $\pm 1 \%$ full-scale reading. \\
\hline 2 & Measuring range & $\begin{array}{l}0-100 \% \text { capacity in } \% \\
0-\infty \text { absorption } \mathrm{m}-1\end{array}$ \\
\hline 3 & Measurement chamber & effective length $0.430 \mathrm{~m} \pm 0.005 \mathrm{~m}$ \\
\hline 4 & Heating Time & $220 \mathrm{~V} \ldots \ldots$...pprox. $20 \mathrm{~min}$ \\
\hline 5 & Light source & Halogen bulb $12 \mathrm{~V} / 5 \mathrm{~W}$ \\
\hline 6 & Colour temperature & $3000 \mathrm{~K} \pm 150 \mathrm{~K}$ \\
\hline 7 & Detector & $\begin{array}{l}\text { Selenium photocell dia. } 45 \mathrm{~mm} \\
\text { Max. sensitivity in light, }\end{array}$ \\
\hline 8 & In Frequency range & $\begin{array}{l}550 \text { to } 570 \mathrm{~nm} \text {. Below } 430 \mathrm{~nm} \text { and above } 680 \mathrm{~nm} \\
\text { sensitivity is less than } 4 \% \text { related to the maximum } \\
\text { sensitivity } \\
2100 \mathrm{C} \text { Temperature at entrance. }\end{array}$ \\
\hline 9 & Maximum Smoke & \\
\hline
\end{tabular}

Fuel Used:-

Diesel was used as fuel in the present work.

\section{Experimental Procedure:-}

In this section, the details of experiments conducted in various modes of operation are presented. All the tests were conducted at the rated speed of $2000 \mathrm{rpm}$. All readings were taken only after the engine attained stable operation. The gas analyzers were switched on before starting the experiments to stabilize them before starting the measurements. All the instruments were periodically calibrated. The injector opening pressure and injection timing were kept constant at the rated value throughout the experiments.

The injection timing is kept constants in all the experiments. The dynamic injection timing was used to calculate the ignition delay. The engine output was varied from no load to full load in steps of $0 \%, 25 \%, 50 \%, 75 \%$ and $100 \%$ in the normal operation of the engine. At each load, the fuel flow rate, air flow rate, exhaust gas temperature, emissions of carbon monoxide, hydrocarbon, and oxides of nitrogen and smoke readings were recorded. The pressures crank angle history of 50 cycles was also recorded by using the data acquisition system and the personal computer. The data was processed to get the average pressure crank angle variation. The experimental work is given below. 
All the experiments were performed at different constant at $1200 \mathrm{rpm}$ which is the engine speed that produces the peak torque. Ultra-low sulfur No. 2 diesel fuel was used for all the engine experiments. The start of injection (SOI) is denoted in degrees after Top Dead Center (ATDC). Most of, but not all, the combinations were tested, as either combustion did not sustain at certain cases or it was not necessary to test certain conditions due to apparently high emissions. A fuel mass of $50 \mathrm{mg} /$ injection was injected. The engine was controlled and monitored using EPA software.

\section{Result and Discussion:- \\ Brake Specific Fuel Consumption (BSFC):-}

Fig 1.shows the variation of brake specific fuel consumption (BSFC) for different injection pressure such as 220 bars, 240 bars for different diesel fuel. The BSFC was decreased at no load to the full load condition. For the injection pressure of 240 and 220bar for diesel of BSFC gradually decreased at no load to full load. With increasing injection pressures in the C.I engine, ignition delay was reduced and the fuel may be completely burnt to produce the large amount of heat energy.

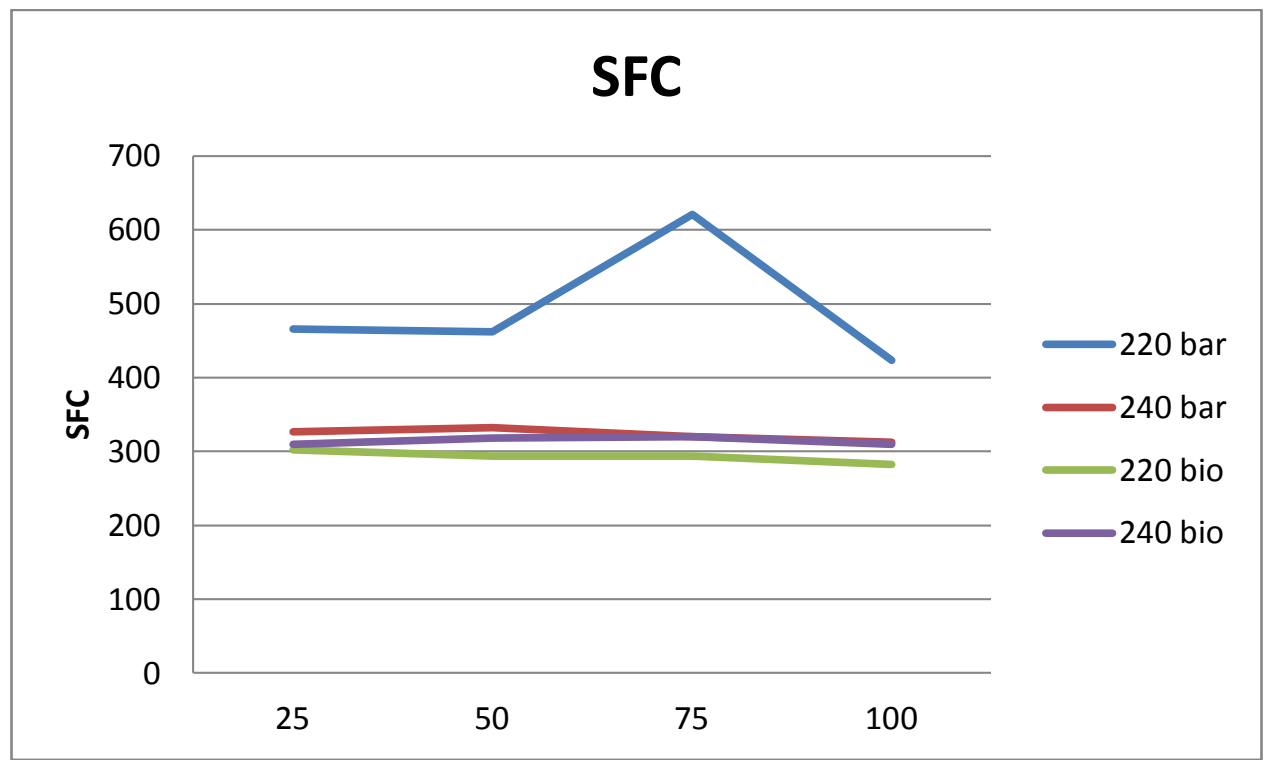

Specific fuel consumption Vs Load

\section{Brake Thermal Efficiency (BTE):-}

Using the twin diesel in constant speed engine the thermal efficiency is slowly increased for the diesel. The maximum thermal efficiency with Bio Diesel fuel oil is about $30 \%$ for 240 bar Nozzle pressure at maximum rated power output. 


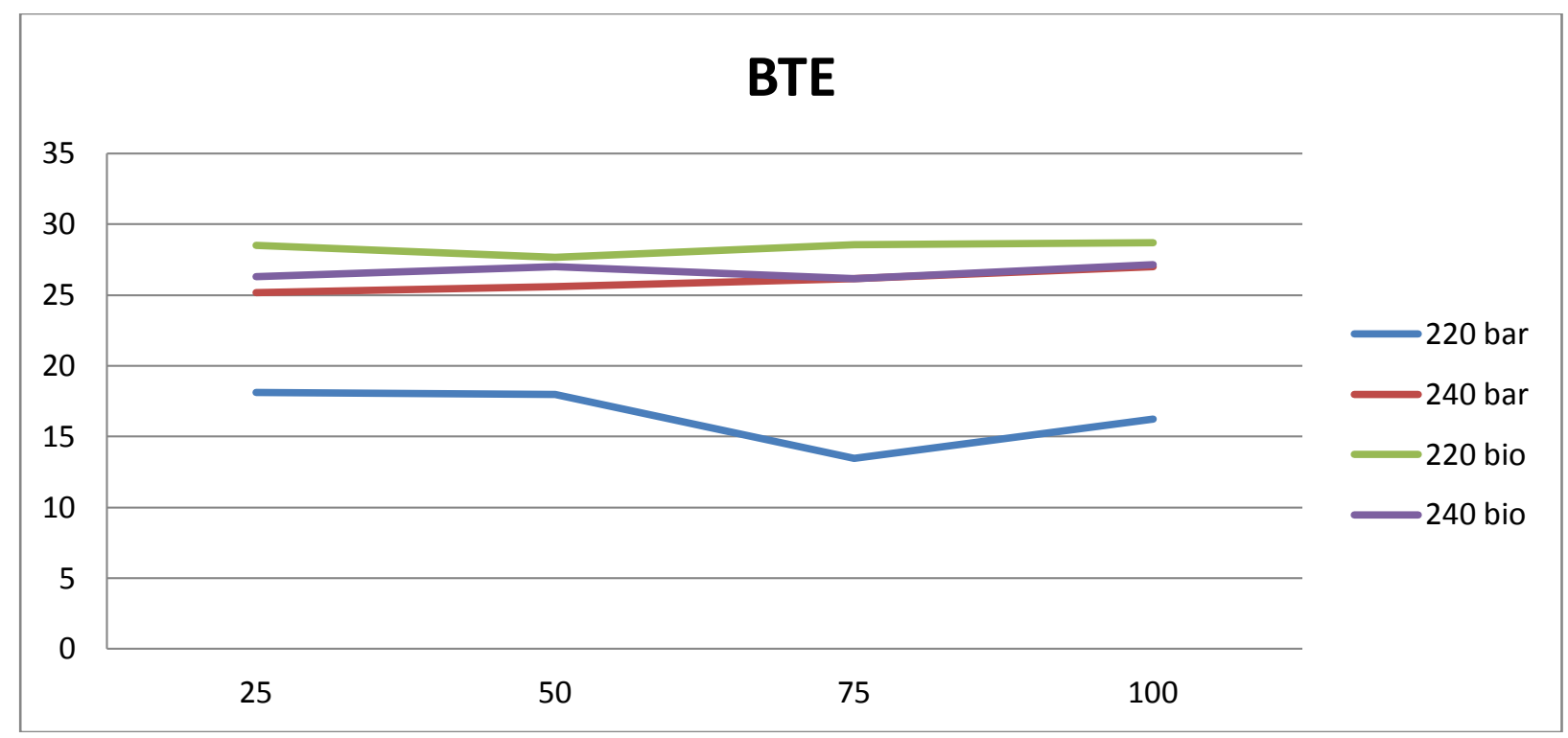

\section{Carbon Monoxide (CO):-}

This shows the variation of $\mathrm{HC}$ and $\mathrm{CO}$ emission with the changing load conditions. The $\mathrm{HC}, \mathrm{CO}$ and $\mathrm{NO}$ emission were analyzed using AVL smoke meter in Twin cylinder engine with different speed and at pressures of 220 and 240 bars, with \& without turbo. The $\mathrm{HC}$ and $\mathrm{CO}$ emission of a diesel engine with decreases $\mathrm{HC}$ emission for no load to full load. For the 10 to $20 \%$ reduced $\mathrm{HC}$ emission is reduced when turbo attached. This is due to the fact that application of turbocharger provides increased air in the engine and enables mixing of fuel-air easily in the combustion chamber, thereby causing better combustion and lower $\mathrm{CO}$ emission values. The emission of unburned hydrocarbon engine with turbocharger is more likely to be reduced because of the decreased quenching distance and the increased lean flammability limit. The higher temperatures in the gases and at the combustion chamber walls of the engine assist in permitting the oxidation reactions to proceed close to completion. This is due to without turbo the emission increased when compared with a turbocharger.

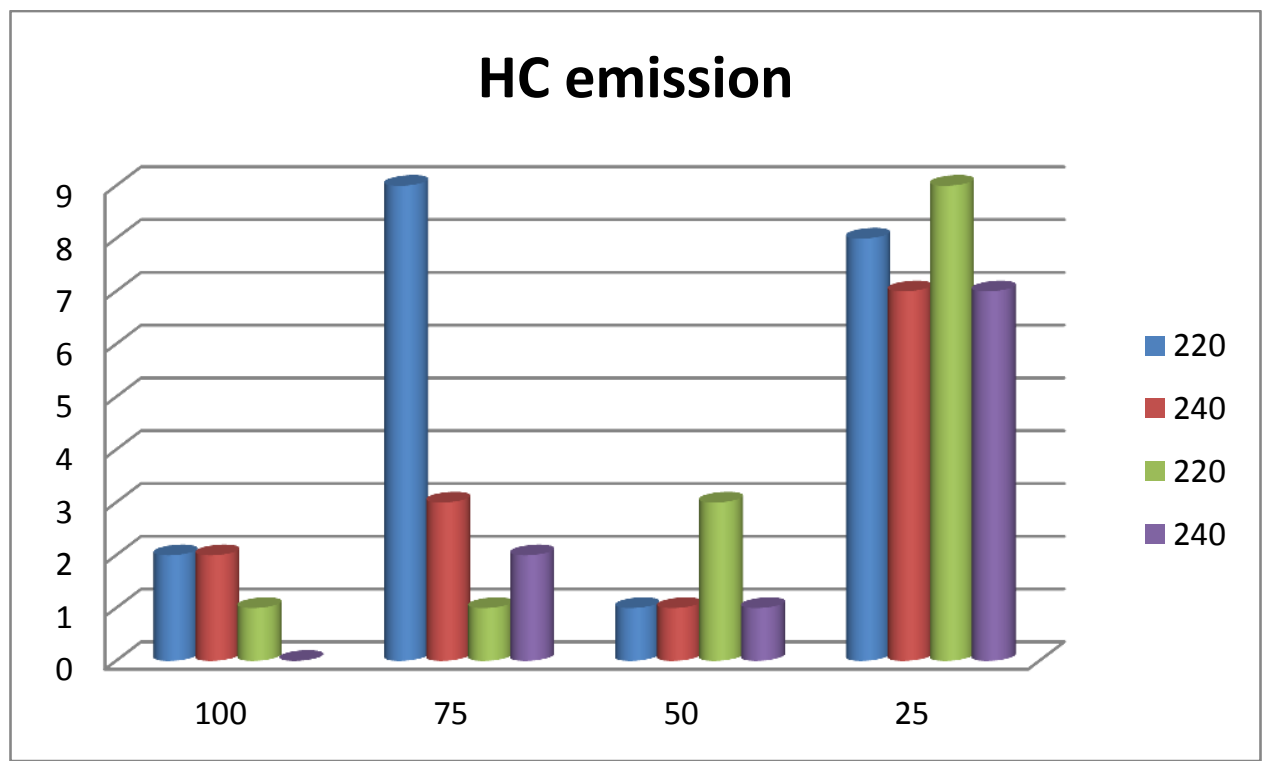




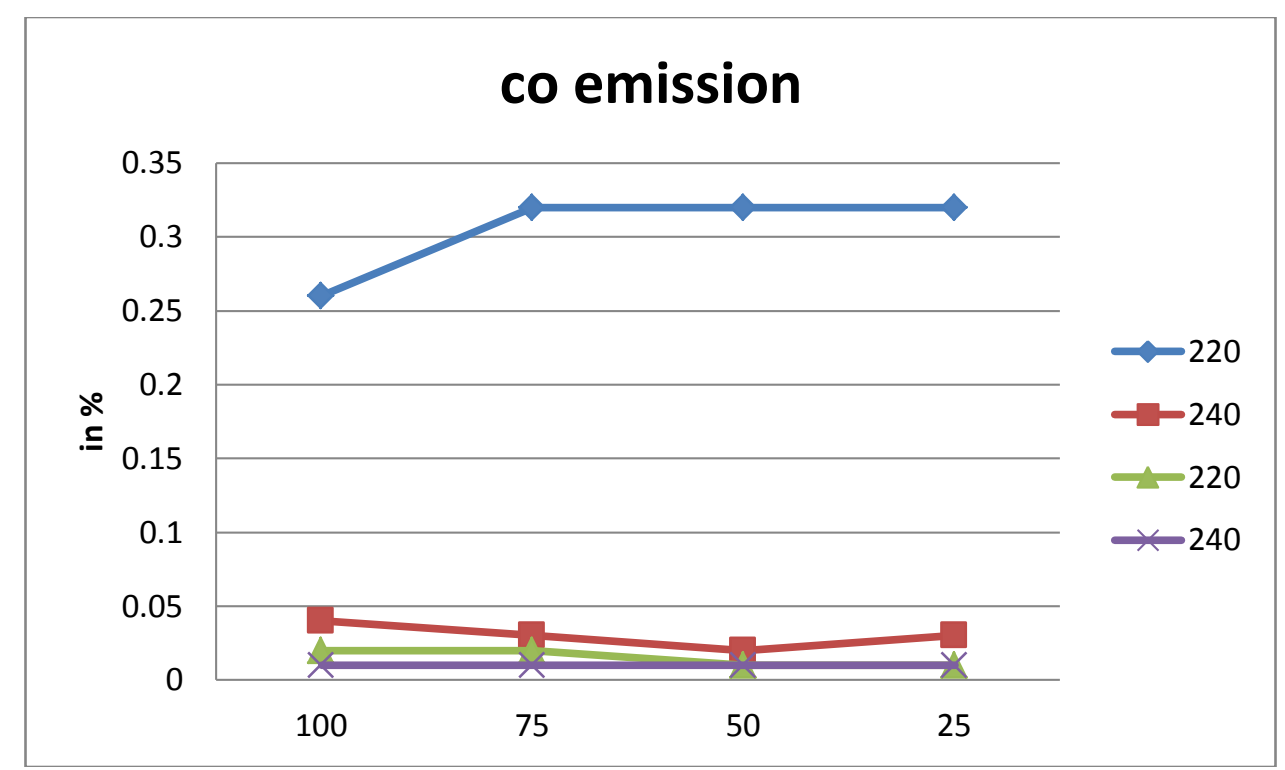

Nitric Oxide (NOx) Emissions:-

Fig shows the NOx emission characteristics for the engine which formed inside the combustion chamber during the combustion process due to the effect of atomic oxygen and nitrogen. Due to without intercooler the exhaust temperature increased, the NOx also continuously increased for 250bar pressure at different load with varies RPM. The NOx emissions of with turbo \& intercooler continuously lesser with the various engine load conditions. A noticeable increase in the NOx emission was observed in the LHR engine with the turbocharger operation. This is due to the fact that application of turbocharger provides more air to the engine and causes a higher combustion temperature which yields an increase in the formation of NOx emission.

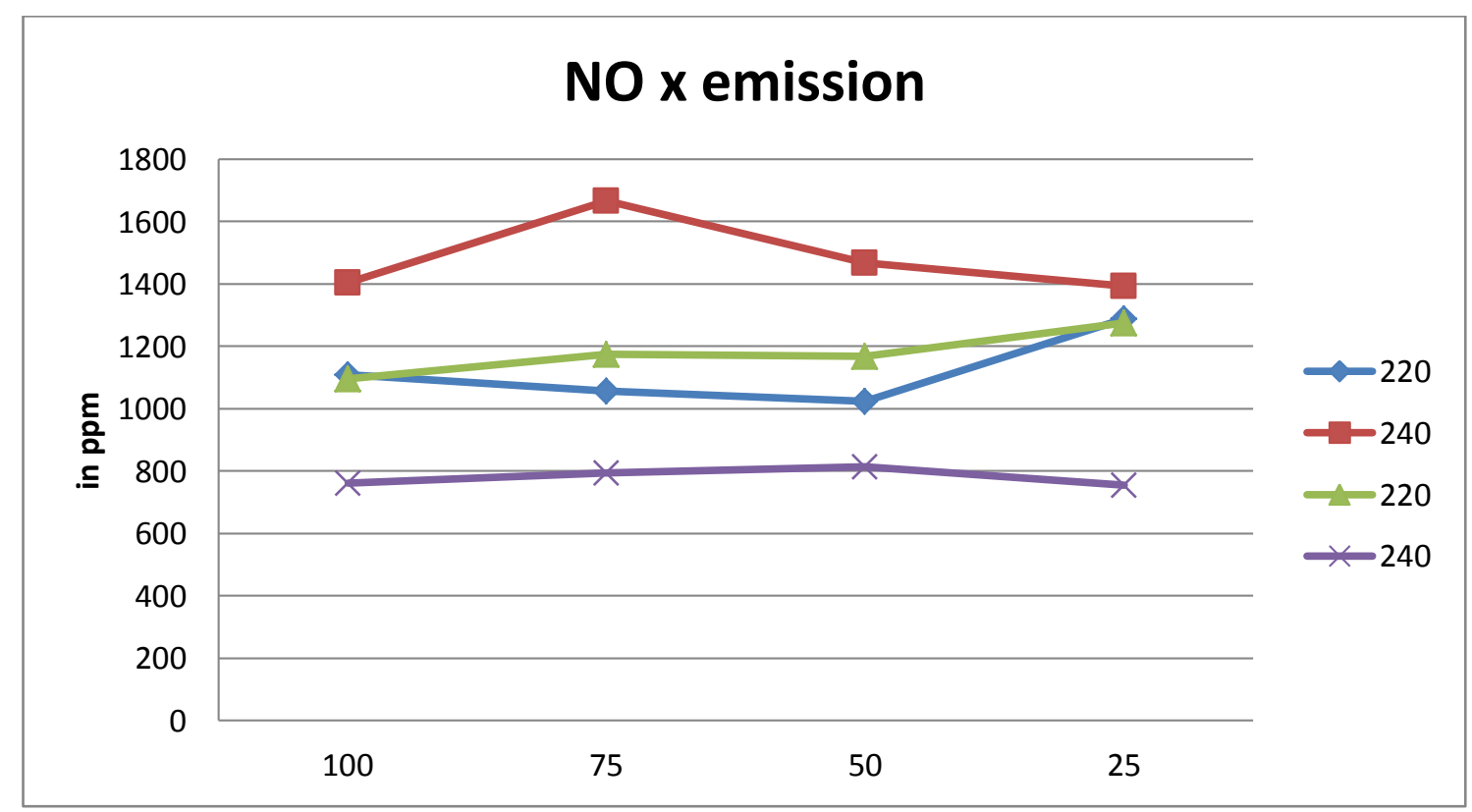

\section{Conclusion:-}

In conclusion, this project is successful following the objective that enhances with and without turbo for various injection pressures in off Road Diesel Engines at Various load conditions. A prototype of turbo system was designed with Fins. The function of this project is totally run well and smoothly towards measuring with and without turbo. The $\mathrm{CO}$ and $\mathrm{HC}$ are decreased when connected with a turbo. And NOx also decreases when connected with a turbo. And the fuel consumption also decreased when the intercooler was connected. The power also increased in turbo without intercooler condition. 